\title{
Pekerja Migran Indonesia dalam Konstelasi Pasar Tenaga Kerja di Era Masyarakat Ekonomi ASEAN ${ }^{1}$
}

\author{
Achmad Zulfikar ${ }^{2}$
}

\section{Pengantar}

Pergerakan manusia dari satu wilayah ke wilayah lain telah menjadi suatu keniscayaan. Namun demikian pergerakan ini menjadi permasalahan, khususnya ketika tidak dikelola dengan baik oleh pemerintah negara. Manusia secara naluriah memiliki insting untuk berpindah dari satu wilayah ke wilayah lain jauh sebelum berbagai konsep dan teori tentang migrasi dilahirkan. Mungkin pembaca tidak asing lagi dengan istilah 'nomaden'. Istilah ini diajarkan melalui literatur pada pendidikan menengah dan atas pada pelajaran Ilmu Pengetahuan Sosial. Nomaden atau berpindah-pindah tempat merupakan aktivitas yang dilakukan oleh leluhur kita dulu, mencari tempat penghidupan hingga mendapatkan tempat yang dianggap representatif untuk kemudianmenetap.

Namun kini kita seakan lupa dengan sejarah bahwa leluhur kita pernah hidup nomaden. Adanya negara, kebijakan, hukum, aturan dan kartu identitas di masa sekarang ini seolah membuat kita melupakan alaminya manusia. Atribut tersebut seolah membatasi ruang gerak manusia untuk hanya berada pada satu wilayah dan tidak boleh melintas ke wilayah lain tanpa kartu identitas (paspor) dan ijin tinggal. Seorang Mukidi, warga negara Indonesia yang bermukim di perbatasan Indonesia-Timor Leste dibatasi aksesnya untuk mengunjungi teman masa kecilnya, Santos yang tinggal di Timor Leste dikarenakan tidak memiliki paspor ataupun kartu identitas melintas lainnya. Seorang Rahing, warga negara Indonesia dari Makassar yang ingin bekerja di Malaysia harus mengurus kartu tenaga kerja dengan prosedur yang panjang untuk dapat bekerja di kebun sawit keluarganya di Sabah, Malaysia.

Dua contoh ini merupakan realita yang kita hadapi sekarang. Kehadiran pemerintah yang diharapkan mampu meregulasi kehidupan bersama justru mengekang akses manusia yang secara naluriah berkarakter nomaden melalui berbagai hukum dan aturandengan konsekuensi terjadinya berbagai penyimpangan yang menjadi ancaman keamanan. Seorang Mukidi jika mengikuti nalurinya sebagai manusia, maka ia bisa secara sembunyi-sembunyi melintas ke Timor Leste untuk bertemu teman masa kecilnya Santos, toh juga ketika masa kecilnya Timor Leste masih bagian dari Indonesia dan pos lintas batas itu belum dibangun, sehingga ia tidak merasa melanggar apa-apa. Didukung lagi tingkat pendidikan yang tidak memadai, karena Mukidi adalah tamatan Sekolah Dasar, maka ia tidak paham aturan imigrasi yang telah dibuat oleh pemerintah. Karakter nomaden yang telah menjadi kebiasaan manusia seperti yang dipraktekkan oleh Mukidi dan Rahing hanyalah potret betapa pentingnya peran pemerintah dalam meningkatkan kesadaran masyarakat melalui berbagai sosialisasi yang sistematis dan efektif terhadap regulasi yang telah dibentuknya. Sehingga kejadian yang

\footnotetext{
${ }^{1}$ Naskah sedang diproses menjadi bagian buku (book chapter) Bunga Rampai Isu-Isu Keamanan NonTradisional di Indonesia

2 S1 Jurusan Hubungan Internasional Universitas Muhammadiyah Yogyakarta; S2 Magister Ilmu Politik Universitas Hasanuddin; S2 Magister Ilmu Hukum Universitas Muslim Indonesia; Sekretaris Jenderal Asosiasi Sarjana Hubungan Internasional Indonesia (ASHII). Email: apa@kabarfikar.com
} 
dialami oleh Mukidi dan Rahing yang merupakan ilustrasi warga Indonesia yang melintas batas untuk keperluan sosial dan mencari kerja menjadi pengunjung ilegal dikarenakan melintas batas tanpa dokumen. Padahal sejatinya mereka hanya mengikuti karakter dasarnya sebagai manusia yang hidup nomaden, justru peran pemerintah yang patut mendapat sorotan atas kejadian yang dialami keduanya. Nah, bagaimana dengan nasib Rahing dari Makassar. Ia merupakan tamatan SMA kelahiran 70-an. Di masa mudanya ia sering pergi ke rumah keluarganya berkebun sawit untuk mencari tambahan penghasilan di Sabah, Malaysia. Tapi akhirnya ia menikah dan kembali ke Makassar untuk waktu yang cukup lama. Kemudian ia merasa perlu lagi mencari tambahan penghasilan untuk keluarganya, akhirnya ia memutuskan untuk membawa serta istri dan anaknya untuk bekerja di kebun sawit keluarganya di Sabah, Malaysia. Ketika ia hendak melintas ke Sabah, ia menemukan fakta bahwa ia harus memiliki kartu tenaga kerja untuk bekerja di luar negeri dan tidak boleh membawa serta keluarga. Ia ngotot kepada petugas imigrasi bahwa dulu saat masih muda tidak ada dokumen yang harus ditunjukkan untuk bekerja di kebun keluarganya sendiri. Rahing kemudian terkena bujuk rayu calo yang berjanji dapat mengantarkan Rahing bersama istri dan anaknya masuk ke Sabah tanpa pemeriksaan imigrasi.

Keuntungan yang Rahing dapat,yakni ia tidak perlu lagi mengurus kartu tenaga kerja yang menurut informasi dari temannya prosedur pengurusannya panjang dan waktu tunggunya sampai 6 bulan. Ia juga dapat membawa serta istri dan anaknya. Keputusan memakai jasa calo ia ambil, akhirnya ia diberangkatkan dengan perahu kecil masuk ke Tawau, salah satu kota di Sabah, Malaysia. Sesampainya di 'pelabuhan', ia bersama penumpang gelap lainnya diciduk oleh Polisi Diraja Malaysia dan dimasukkan ke sel tahanan. Ia harus membayar mahal ke calo, dan ia juga harus ditahan hingga mengikuti proses pengadilan. Padahal, Rahing hanya mengikuti nalurinya dan juga pengalaman sebelumnya. Dikarenakan telah berlakunya UU No. 39 Tahun 2004 (bahkan kini telah direvisi menjadi UU No. 18 Tahun 2017) yang mengharuskan TKI mengurus dokumen yang dipersyaratkan, maka secara prosedur di dalam negeri ia sudah bermasalah.Apalagi ia membawa serta istri dan anaknya yang jelas-jelas di dalam UU tersebut dilarang. Lalu setelah ia ditangkap oleh Polisi di Malaysia dan juga secara administratif bermasalah di Indonesia, negerinya sendiri, kemana ia harus mengadu. Fakta ini kembali menunjukkan bahwa kebijakan yang dibuat oleh pemerintah kita akhirnya menjadi dilematis ketika berada pada tataran praktis di lapangan.

Fakta-fakta di atas cukup membuka mata kita bahwa saat ini kita telah jauh melupakan sejarah. Bahkan kita cenderung ingin menghilangkan sejarah bahwa secara naluriah manusia itu nomaden dan tidak bisa dibatasi ruang geraknya. Hal ini secara global sudah mulai disadari dan dibenahi. Perserikatan Bangsa-Bangsa (PBB) bersama 193 negara anggotanya pada 19 September 2016 lalu mengadakan pertemuan tingkat tinggi tentang pengungsi dan migran dan menghasilkan deklarasi politik berbentuk New York Declaration for Refugees and Migrants. Deklarasi ini dibuka dengan pengakuan sebagai berikut:

"Since earliest times, humanity has been on the move. Some people move in search of new economic opportunities and horizons. Others move to escape armed conflict, poverty, food insecurity, persecution, terrorism, or human rights violations and abuses. Still others do so in response to the adverse effects of climate change, natural disasters (some of which may be 
linked to climate change), or other environmental factors. Many move, indeed, for a combination of these reasons".

Pernyataan di atas mengakui bahwa sejak awal kali keberadaannya, manusia telah bergerak. Beberapa orang bergerak untuk mencari peluang ekonomi baru dan menjelajah cakrawala. Lainnya berpindah untuk melarikan diri dari konflik bersenjata, kelaparan, kerawanan pangan, penganiayaan, terorisme atau pelanggaran hak asasi manusia dan kekerasan. Sementara lainnya berpindah dikarenakan merespon perubahan iklim dan bencana alam dan faktor lingkungan lainnya. Pergerakan lainnya kemungkinan terjadi karena kombinasi alasan-alasan tersebut.

Hal ini membawa konsekuensi bagi dunia bahwa kita hari ini harus mempertimbangkan bagaimana masyarakat internasional dapat memberikan respon terbaik untuk fenomena pertumbuhan global dari besarnya pergerakan pengungsi dan migran. Kita saksikan di dunia saat ini tingkat mobilitas manusia belum pernah terjadi sebelumnya. Lebih banyak orang saat ini dibandingkan saat kita dilahirkan. Migran hadir di semua negara di dunia. Sebagian besar dari mereka bergerak tanpa insiden. Pada 2015, jumlah mereka melampaui 244 juta, tumbuh pada tingkat lebih cepat dari populasi dunia. Namun ada sekitar 65 juta orang secara paksa, termasuk lebih dari 21 juta pengungsi, 3 juta pencari suaka dan lebih dari 40 juta pengungsi yang dipindahkan di dalam negerinya secara paksa.

Komitmen yang melibatkan seluruh negara di dunia yang tergabung dalam PBB ini tentu patut disikapi secara strategis. Indonesia yang merupakan salah satu negara dengan jumlah penduduk terbesar sebanyak 250 juta jiwa patut berbenah diri merespon komitmen global ini. Demikian juga dengan ASEAN sebagai organisasi di kawasan Asia Tenggara, komitmen global di atas patut mendapatkan perhatian lebih mengingat Asia Tenggara merupakan salah satu kawasan penopang ekonomi dunia. Selanjutnya, pemerintah Indonesia memiliki tanggung jawab kepada warga negaranya yang melakukan migrasi kerja ke luar negeri untuk mendapatkan perlindungan yang memadai serta jaminan keamanan oleh negara tujuan kerja agar migrasi kerja dapat berjalan secara aman dan nyaman.

Di tingkat regional, pemerintah Indonesia juga harus mendorong kerjasama yang lebih komprehensif antar-negara anggota ASEAN untuk mewujudkan cita-cita pendirian ASEAN sebagaimana disebutkan dalam The ASEAN Declaration,yakni tujuan pertama untuk mempercepat pembangunan ekonomi, kemajuan sosial, dan perkembangan kejayaan di kawasan guna memperkuat dasar bagi sebuah komunitas yang sejahtera dan damai di Asia Tenggara, serta tujuan kedua untuk meningkatkan perdamaian dan stabilitas kawasan.

Dalam rangka mewujudkan tujuan ASEAN tersebut, sejak 31 Desember 2015 Indonesia bersama sembilan negara anggota ASEAN lainnya, yakni: Brunei Darussalam, Filipina, Malaysia, Singapura, Thailand, Vietnam, Laos, Myanmar dan Kamboja telah memasuki babak baru dalam kerangka ASEAN Community. Komunitas ini terdiri atas tiga pilar, yakni: ASEAN Political and Security Community (APSC)/Masyarakat Politik dan Keamanan ASEAN, ASEAN Economic Community (AEC)/Masyarakat Ekonomi ASEAN, dan ASEAN Socio-Cultural Community (ASCC)/Masyarakat Sosial Budaya ASEAN.

Indonesia dan negara anggota ASEAN saat ini telah memasuki era Masyarakat Ekonomi ASEAN. Topik yang menarik untuk dikaji dari MEA yang berkaitan dengan migrasi kerja yakni pasar tunggal ASEAN dan basis produksi yang terdiri atas lima elemen, 
antara lain: (1) barang (free flow of goods), (2) jasa (free flow of services), (3) investasi (free flow of investment), (4) modal (free flow of capital) dan (5) tenaga kerja terampil (free flow of skilled labour).Migrasi kerja dalam pilar ini diwakili elemen tenaga kerja terampil. Sumber daya manusia merupakan kekuatan Indonesia dikarenakan negara ini memiliki jumlah penduduk terbesar di antara negara anggota ASEAN dan juga negara dengan penduduk terbesar keempat di dunia. Sehingga Indonesia memiliki potensi yang luar biasa untuk mengekspansi pasar tenaga kerja di ASEAN dengan pekerja migran Indonesia/tenaga kerja Indonesia (PMI/TKI) yang dimiliki.

Tulisan ini akan mengurai lebih lanjut bagaimana pekerja migran Indonesia dapat berdaya saing dalam konstelasi pasar tenaga kerja di era masyarakat ekonomi ASEAN yang telah mulai berlaku sejak 31 Desember 2015 dan saat ini telah berlangsung selama 1 tahun. Pembahasan dalam tulisan ini terdiri atas dua bagian. Pertama menjelaskan kondisi pekerja migran Indonesia dan kedua menguraikan pekerja migran Indonesia dalam masyarakat ekonomi ASEAN.

\section{Kondisi Pekerja Migran Indonesia}

\section{Statistik}

Sebelum membahas lebih lanjut mengenai kondisi pekerja migran Indonesia, terlebih dahulu kita harus memahami beberapa istilah terkait ketenagakerjaan. Pertama, ketenagakerjaan adalah segala hal yang berhubungan dengan tenaga kerja pada waktu sebelum, selama, dan sesudah masa kerja (Pasal 1 UU No. 13 Tahun 2003). Kedua, tenaga kerja adalah setiap orang yang mampu melakukan pekerjaan guna menghasilkan barang dan/atau jasa baik untuk memenuhi kebutuhan sendiri maupun untuk masyarakat (Pasal 1 UU No. 13 Tahun 2003). Ketiga, pekerja/buruh adalah setiap orang yang bekerja dengan menerima upah atau imbalan dalam bentuk lain (Pasal 1 UU No. 13 Tahun 2003).

Lebih spesifik lagi terkait pekerja migran. Pertama, pekerja Migran Indonesia/Tenaga Kerja Indonesia (TKI) adalah setiap warga negara Indonesia yang memenuhi syarat untuk bekerja di luar negeri dalam hubungan kerja untuk jangka waktu tertentu dengan menerima upah. (Pasal 1 UU No. 39 Tahun 2004) Pasal 35 UU No. 39/2004 menjelaskan syarat-syarat TKI untuk bekerja di luar negeri, antara lain: (1) berusia sekurang-kurangnya 18 tahun, kecuali bagi calon TKI yang dipekerjakan pada pengguna perseorangan/rumah tangga sekurang-kurangnya berusia 21 tahun; (2) sehat jasmani dan rohani; (3) tidak dalam keadaan hamil bagi calon tenaga kerja perempuan; (4) berpendidikan sekurang-kurangnya lulus SLTP atau yang sederajat; (5) terdaftar di Dinas Ketenagakerjaan di daerah tempat tinggalnya; (6) memiliki dokumen lengkap. Pada tahun 2006, pemerintah Indonesia mengamanatkan pembentukan BNP2TKI (Badan Nasional Penempatan dan Perlindungan Tenaga Kerja Indonesia) Badan ini merupakan badan yang dibentuk pemerintah untuk mengurus Tenaga Kerja Indonesia (TKI) di Luar Negeri atau saat ini disebut Pekerja Migran Indonesia berdasarkan UU No. 39 Tahun 2004 tentang Penempatan dan Perlindungan Tenaga Kerja Indonesia di Luar Negeri (PPTKILN) dan Peraturan Presiden No. 81 Tahun 2006 tentang BNP2TKI.

Setelah diberlakukannya UU No. 18 Tahun 2017 tentang Perlindungan Pekerja Migran Indonesia, maka pengertian Tenaga Kerja Indonesia yang kini telah secara tegas 
diistilahkan Pekerja Migran Indonesia adalah setiap warga negara Indonesia yang akan, sedang, atau telah melakukan pekerjaan dengan menerima upah di luar wilayah Republik Indonesia. Sedangkan syarat-syarat bagi pekerja migran Indonesia yang akan bekerja di luar negeri sesuai UU terbaru harus memenuhi persyaratan: (1) berusia minimal 18 (delapan belas) tahun; (2) memiliki kompetensi; (3) sehat jasmani dan rohani; (4) terdaftar dan memiliki nomor kepesertaan Jaminan Sosial; dan (5) memiliki dokumen lengkap yang dipersyaratkan.

Jika dibandingkan antara aturan lama dan aturan terbaru poin yang dipersyaratkan hanya mejadi lima, sedangkan terdapat persyaratan tambahan yakni memiliki kompetensi yang sebelumya tidak masuk persyaratan utama, sedangkan poin persyaratan yang dihilangkan yakni tidak dalam keadaan hamil, pendidikan sekurang-kurangnya lulus SLTP dan terdaftar di Dinas Ketenagakerjaan di daerah tempat tinggalnya. Poin persyaratan ini sebagaimana asas yang dianut dalam UU terbaru yakni keterpaduan, persamaan hak, pengakuan atas martabat dan hak asasi manusia, demokrasi, keadilan sosial, kesetaraan dan keadilan gender, nondiskriminasi, anti-perdaganganmanusia, transparansi, akuntabilitas dan berkelanjutan.

BNP2TKI sebagai pelaksana tugas pemerintah di bidang perlindungan pekerja migran Indonesia bersama Kementerian Ketenagakerjaan yang dalam UU baru menyesuaikan nama dengan nomenklatur UU. Badan ini bertugas sebagai pelaksana kebijakan dalam pelayanan Pelindungan Pekerja Migran Indonesia secara terpadu. Setiap tahunnya, BNP2TKI mengumpulkan data penempatan tenaga kerja Indonesia melalui Pusat Penelitian, Pengembangan dan Informasi. Data ini kemudian dipublikasikan secara berkala. Adapun data penempatan TKI dalam 6 tahun terakhir (2011-November 2016), sebagai berikut:

\section{Grafik 1.Penempatan Tenaga Kerja Indonesia Tahun 2011-Nov. 2016}

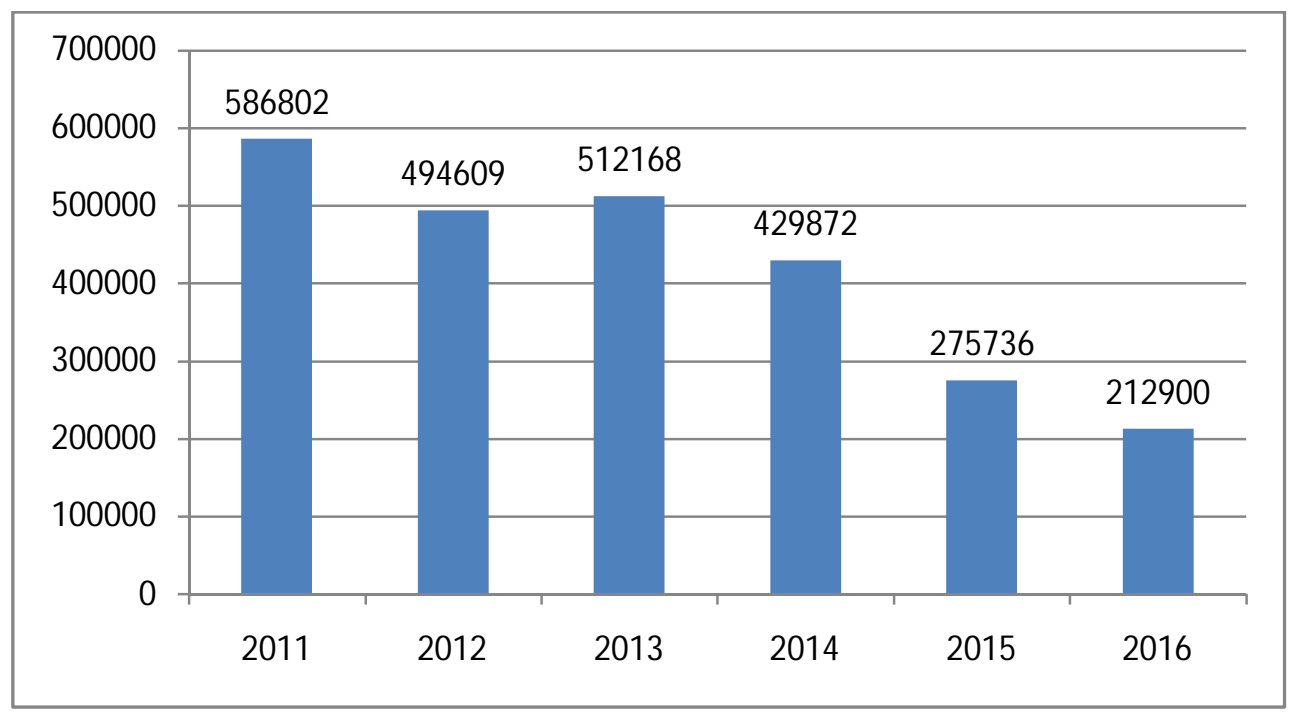

Sumber: BNP2TKI, Data Penempatan dan Perlindungan TKI, 2016

Data di atas menunjukkan penempatan TKI dari tahun 2011 hingga 2016 terus mengalami penurunan yang signifikan. Walaupun pada tahun 2013 sempat mengalami kenaikan, tetapi penempatan TKI pada tahun 2015 jika dibandingkan tahun sebelumnya 
(2014) mengalami penurunan yang drastis. Kondisi ini terus berlanjut hingga November 2016. Selanjutnya, Pekerja migran Indonesia tersebar di 152 negara. Adapun 25 negara penempatan dengan jumlah TKI terbesar dipaparkan sebagai berikut:

Tabel 1. Negara Penempatan Tenaga Kerja Luar Negeri Indonesia Periode 2011-Nov. 2016

\begin{tabular}{|c|c|c|c|c|c|c|c|}
\hline \multirow{2}{*}{ No. } & \multirow{2}{*}{ Negara } & \multicolumn{6}{|c|}{ Tahun } \\
\hline & & $2011 *$ & $2012 * *$ & $2013 * *$ & $2014 * *$ & $2015^{* *}$ & $2016 * * *$ \\
\hline 1. & Malaysia & 134.120 & 134,069 & 150,250 & 127,827 & 97,635 & 80,906 \\
\hline 2. & Taiwan & 78.865 & 81,071 & 83,544 & 82,665 & 75,303 & 70,379 \\
\hline 3. & Saudi Arabia & 137.835 & 40,655 & 45,394 & 44,325 & 23,000 & 12,931 \\
\hline 4. & Hongkong & 50.301 & 45,478 & 41,769 & 35,050 & 15,322 & 13,072 \\
\hline 5. & Singapura & 47.786 & 41,556 & 34,655 & 31,680 & 20,895 & 15,037 \\
\hline 6. & Uni Emirat Arab & 39.917 & 35,888 & 44,505 & 17,962 & 7,619 & 2,430 \\
\hline 7. & Qatar & 16.616 & 20,380 & 16,237 & 7,862 & 2,460 & 1,233 \\
\hline 8. & Korea Selatan & 11.392 & 13,593 & 15,374 & 11,848 & 5,501 & 3,646 \\
\hline 9. & Amerika Serikat & 13.749 & 15,353 & 15,021 & 9,233 & 1,029 & 238 \\
\hline 10. & Oman & 7.306 & 10,719 & 10,719 & 10,719 & 6,766 & 928 \\
\hline 11. & Brunei Darussalam & 10.804 & 13,146 & 11,269 & 11,616 & 9,993 & 7,567 \\
\hline 12. & Bahrain & 4.379 & 6,328 & 5,384 & 5,472 & 2,570 & - \\
\hline 13. & Jepang & 2.508 & 3,293 & 3,042 & 2,428 & 468 & - \\
\hline 14. & Italia & 3.408 & 3,691 & 3,746 & 1,295 & 1,516 & 831 \\
\hline 15. & Kuwait & 2.723 & 2,518 & 2,534 & 1,714 & 210 & 901 \\
\hline 16. & China & 1.072 & 1,967 & 2,055 & 915 & 108 & 64 \\
\hline 17. & Spanyol & 1.484 & 1,746 & 1,417 & 889 & 268 & 115 \\
\hline 18. & Turki & 1.016 & 1,209 & 1,518 & 1,246 & 1,108 & 492 \\
\hline 19. & Afrika Selatan & 1.272 & 1,388 & 905 & 587 & 113 & - \\
\hline 20. & Mauritius & 478 & 982 & 1,017 & 838 & 144 & - \\
\hline 21. & Thailand & 1.113 & 1,035 & 1,041 & 717 & 90 & - \\
\hline 22. & Belanda & 592 & 798 & 1,176 & 796 & 52 & - \\
\hline 23. & Kepulauan Fiji & 556 & 970 & 848 & 902 & 246 & - \\
\hline 24. & Australia & 526 & 945 & 1,012 & 644 & 77 & - \\
\hline 25. & Jerman & 299 & 697 & 1,168 & 556 & 194 & - \\
\hline 26. & Lainnya & 59.059 & 17,017 & 16,568 & 11,664 & 3,049 & 2,130 \\
\hline & Total & 586.802 & 494,609 & 512,168 & 429,872 & 275,736 & 212,900 \\
\hline
\end{tabular}

Sumber: BNP2TKI, Data Penempatan dan Perlindungan TKI,*2011-2013; **2015; ***Nov. 2016

Data di atas menunjukkan Malaysia merupakan negara tujuan dengan penempatan tertinggi setiap tahun selama 6 tahun terakhir (2011-2016). Di posisi berikutnya adalah Taiwan, Saudi Arabia, Hongkong dan Singapura di urutan kelima. Lebih lanjut, kondisi TKI di Negara Anggota ASEAN dipaparkan sebagai berikut: 
Grafik 2. Kondisi TKI di Negara Anggota ASEAN

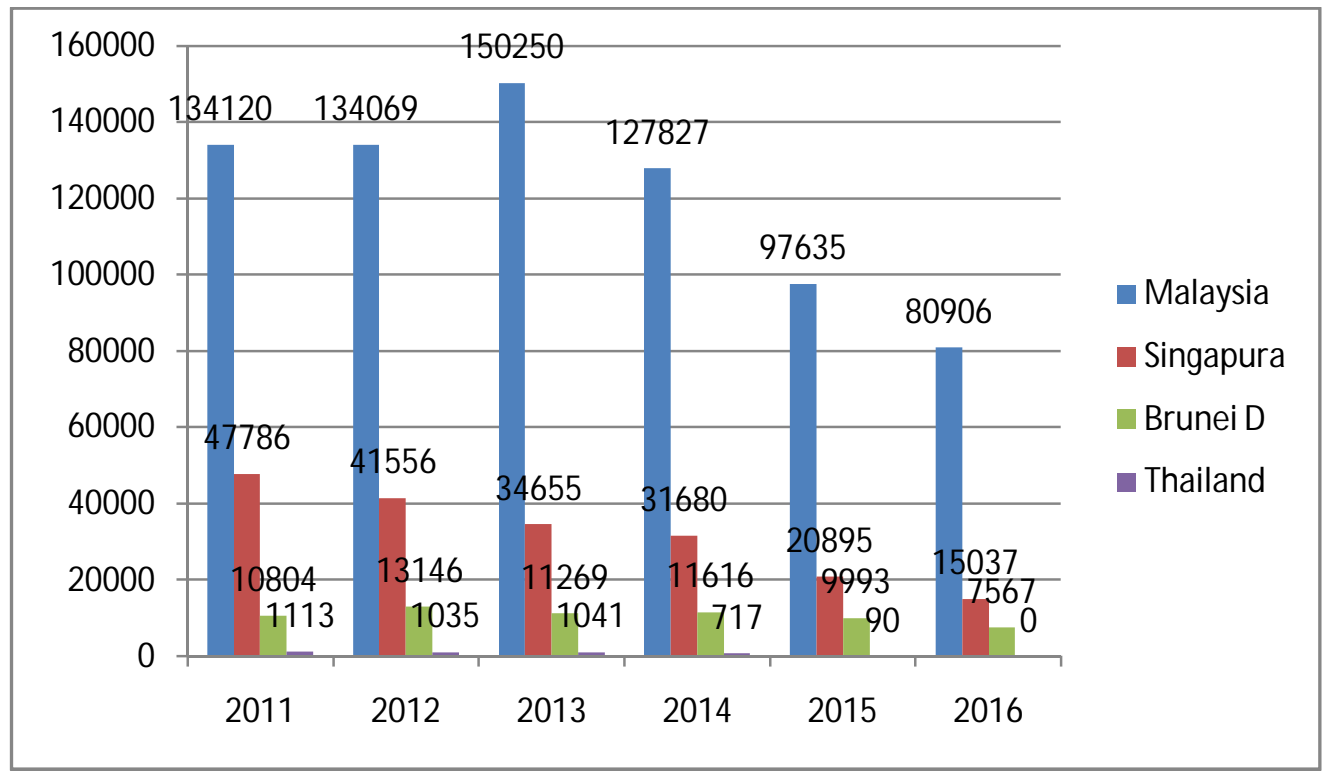

Sumber: Diolah oleh Penulis dari data BNP2TKI

Penempatan pekerja migran Indonesia/Tenaga kerja Indonesia (PMI/TKI) di negaranegara anggota ASEAN pada data Negara Penempatan Tenaga Kerja Luar Negeri Indonesia menunjukkan hanya empat negara yang masuk dalam 25 besar negara penempatan yakni Malaysia (urutan 1), Singapura (urutan 5), Brunei Darussalam (urutan 11) dan Thailand (urutan 21). Data di atas lebih spesifik menunjukkan kondisi TKI di negara-negara tersebut. Jika diperhatikan secara seksama, penempatan TKI di Malaysia relatif stabil pada 2011 dan 2012, kemudian terjadi peningkatan pada 2013 dan penurunan kembali pada 2014. TKI pada tahun 2015 mengalami penurunan yang cukup besar jika dibandingkan tahun-tahun sebelumnya. Demikian juga yang terjadi di Singapura dan Brunei Darussalam. Bahkan, penempatan TKI di Thailand sampai November 2016 belum ada. Selanjutnya dipaparkan posisi/jabatan yang ditempati oleh TKI di negara penempatan, sebagai berikut:

Tabel 2. Jabatan TKI di Negara Penempatan Periode 2011-2016

\begin{tabular}{|c|c|c|c|c|c|c|c|}
\hline \multirow{2}{*}{ No. } & \multirow{2}{*}{ Jabatan } & \multicolumn{6}{|c|}{ Tahun } \\
\hline & & $2011 *$ & $2012 * *$ & $2013 * *$ & $2014 * *$ & $2015 * *$ & $2016 * * *$ \\
\hline 1. & Dosmetic Worker & 267.231 & 164.981 & 168.318 & 133.390 & 52.328 & 40.348 \\
\hline 2. & Caregiver/Caretaker & 48.492 & 52.565 & 48.188 & 49.069 & 44.941 & 49.449 \\
\hline 3. & Plantation Worker & 39.622 & 36.478 & 47.598 & 47.790 & 38.526 & 29.037 \\
\hline 4. & Operator & 40.847 & 40.347 & 46.799 & 38.836 & 35.187 & 28.340 \\
\hline 5. & Deck Hand & - & 12.283 & 11.249 & 10.410 & 1.166 & - \\
\hline 6. & Lainnya & 191.610 & 187.955 & 190.016 & 150.377 & 103.588 & 65.726 \\
\hline & Total Keseluruhan & 586.802 & 494,609 & 512,168 & 429,872 & 275,736 & 212.900 \\
\hline
\end{tabular}

Sumber: BNP2TKI, Data Penempatan dan Perlindungan TKI, *2011-2013; **2015; ***Nov. 2016

Data di atas menunjukkan 5 jabatan teratas yang ditempati oleh TKI di negara penempatan. Posisi pertama ditempati oleh TKI yang bekerja sebagai domestic worker / penata laksana rumah tangga, selanjutnya caregiver/caretaker di posisi kedua, posisi ketiga 
ditempati plantation worker, posisi keempat oleh operator dan posisi kelima ditempati deck hand. Posisi kelima ini mengalami penurunan yang drastis di tahun 2015, bahkan hingga November 2016 sama sekali tidak ada penempatan. Hal ini menunjukkan bahwa pekerja migran Indonesia di luar negeri masih berada pada kategori tenaga kerja tidak terampil/berketerampilan rendah seperti domestic worker/penata laksana rumah tangga, caregiver/caretaker dan plantation worker. maupun tenaga kerja semi-terampil pada posisi operator maupun deck hand.

Berdasarkan data di atas maka dapat dipahami bahwa kondisi pekerja migran Indonesia yang digambarkan melalui data statistik secara keseluruhan menunjukkan bahwa angka penempatan TKI/PMI secara prosedural semakin menurun dari tahun ke tahun.Jika berbicara dalam konstelasi pasar tenaga kerja ASEAN, TKI/PMI mayoritas masih menempatkan Malaysia sebagai negara tujuan dengan jumlah terbesar mencapai hampir seperempat dari jumlah penempatan TKI setiap tahunnya, diikuti Singapura, Brunei Darussalam dan Thailand. Sedangkan tenaga kerja yang ditempatkan juga masih berada pada kategori tidak terampil dan semi terampil. Kedua hal ini patut menjadi pertimbangan pemerintah untuk mengambil kebijakan yang efektif dalam mengelola TKI/PMI.

\section{Kebijakan}

Migrasi tenaga kerja dari Indonesia sesungguhnya telah terjadi selama ratusan tahun, tapi meningkat secara tajam pada era 1960-an dan 1970-an hingga sekarang. Tenaga kerja dari Indonesia bekerja di luar negeri karena beberapa alasan, termasuk kurangnya peluang kerja, kemiskinan, dan perbedaan gaji di Indonesia dengan negara tujuan. Pengurusan penempatan tenaga kerja Indonesia (TKI) secara resmi oleh pemerintah Indonesia baru dimulai pada 1969. (Kemenakertrans, 2011:36)

Peraturan Pemerintah No. 4 Tahun 1970 tentang program penempatan Angkatan Kerja Antar Daerah (AKAD) dan Antar Kerja Antar Negara (AKAN) diperkenalkan sebagai jalan untuk melibatkan sektor swasta dalam industri perekrutan dan penempatan tenaga kerja. Meskipun jumlah TKI berfluktuasi antara 1996 dan 2007, namun jumlahnya meningkat dari 517.169 menjadi 696.746 antara 2004 dan 2007. Sekitar 60 persen TKI berada di negaranegara Timur Tengah seperti Arab Saudi, Kuwait, Uni Emirat Arab, Jordan dan Qatar. Sisanya berada di negara-negara Asia Tenggara dan Asia Timur seperti Malaysia, Singapura, Hong Kong, Korea Selatan, Taiwan dan Amerika. (Kemenakertrans, 2011:36)

Banyak kebijakan ditetapkan untuk mengelola penempatan TKI dengan lebih baik. Pemerintah Indonesia memperkuat aturan perundang-undangan untuk melindungi TKI, diantaranya pengesahan Undang-Undang No. 39 Tahun 2004 tentang Penempatan dan Perlindungan Tenaga Kerja Indonesia di Luar Negeri (PPTKILN) pada tahun 2004. Diperkuat lagi dengan pengesahan Peraturan Presiden No. 81 Tahun 2006 tentang pendirian BNP2TKI yang merupakan badan pemerintah dengan tugas untuk mengelola TKI dan membuat kebijakan yang efektif bagi penempatan dan perlindungan TKI.Selain itu pada tahun 2007, Indonesia mengesahkan Undang-Undang No. 21 Tahun 2007 tentang Pemberantasan Tindak Pidana Perdagangan Orang yang diinspirasi dari instrumen hukum PBB yang bernama "Protocol to Prevent, Suppress and Punish Traffi cking in Persons, Especially Women and Children" biasa disebut Protokol Palermo. Protokol ini ditandatangani Indonesia di akhir 2001. 
Indonesia pada tahun 2012 juga telah meratifikasi Konvensi Internasional Perlindungan Hak Pekerja Migran melalui Undang-Undang No. 6 Tahun 2012 tentang pengesahan International Convention on the Protection of The Rights Of All Migrant Workers and Members of Their Families (Konvensi Internasional mengenai Perlindungan Hak-Hak Seluruh Pekerja Migran dan Anggota Keluarganya). Konvensi ini menjadi rujukan bagi pemerintah dalam menetapkan standar perlindungan hak-hak pekerja migran Indonesia dalam perubahan atas Undang-Undang No. 39 Tahun 2004 yang saat ini telah menjadi Rancangan Undang-Undang Perlindungan Pekerja Migran Indonesia.

Selain itu di tataran teknis pemerintah juga membuat turunan dari UU No. 39 Tahun 2004, yaitu: (1) Peraturan Pemerintah Nomor 3 Tahun 2013 tentang Perlindungan TKI di Luar Negeri, (2) Peraturan Pemerintah Nomor 4 Tahun 2013 tentang Tata Cara Pelaksanaan Penempatan oleh Pemerintah, dan (3) Peraturan Pemerintah Nomor 5 Tahun 2013 tentang Tata Cara Penilaian dan Penetapan Mitra Usaha dan Pengguna Perseorangan.

Perlindungan TKI yang diatur dalam PP No. 3 Tahun 2013 tentang Perlindungan TKI di Luar Negeri. Hal yang diatur yakni pembagian kerja antara BNP2TKI dan Kementerian Luar Negeri. Adapun tanggungjawab pada masa pra-penempatan dan pasca-penempatan ditangani oleh BNP2TKI/BP3TKI sedangkan pada masa penempatan merupakan tanggungjawab Kementerian Luar Negeri melalui Kedutaan Besar/Konsulat Jenderal Republik Indonesia yang kemudian melimpahkannya ke bagian yang menangani bidang Ketenagakerjaan, di beberapa KBRI/KJRI yang wilayah kerjanya terdapat banyak TKI, maka Kementerian Ketenagakerjaan menunjuk Atase Bidang Ketenagakerjaan.

PP No. 3 Tahun 2013 mengamanatkan kepada Kementerian Luar Negeri yang kemudian menjadi tanggungjawab dari KBRI/KJRI di negara tujuan TKI untuk memberikan perlindungan terhadap hak-hak TKI di luar negeri. Pada dasarnya keberadaan WNI di luar negeri dan juga TKI di negara penempatan merupakan hal yang sama. Namun permasalahan yang sering dihadapi oleh KBRI di negara tujuan TKI, seperti Malaysia yang merupakan salah satu negara anggota ASEAN banyak disebabkan TKI yang tidak berdokumen lengkap atau bahkan ilegal.

Setelah menempuh proses yang panjang selama 7 tahun, revisi UU No. 39 Tahun 2004 akhirnya disepakati antara Pemerintah dan Dewan Perwakilan Rakyat RI dalam Rapat Paripurna DPR RI. Revisi UU tersebut adalah Undang-Undang Nomor 18 Tahun 2017 tentang Perlindungan Pekerja Migran Indonesia. Ketua Komisi IX DPR RI Dede Yusuf dikutip Bisnis menyatakan dalam UU yang baru ini, pemerintah memastikan kehadirannya mulai dari proses perekrutan, penempatan, hingga setelah penempatan para buruh migran di luar negeri. Sebelumnya, proses-proses tersebut tidak diikuti dengan sistem perlindungan yang menyeluruh bagi para buruh migran di luar negeri. Dengan berlakunya UU ini, maka UU No. 39 Tahun 2004 dicabut dan dinyatakan tidak berlaku, dan semua peraturan perundang-undangan yang merupakan pelaksanaan dari UU No. 39 Tahun 2004 dinyatakan masih tetap berlaku sepanjang tidak bertentangan dengan ketentuan dalam UU yang telah diberlakukan.

Dari penjelasan di atas, maka dapat dipahami bahwa peran negara dalam mempersiapkan TKI ke luar negeri lebih dititikberatkan pada upaya pengerahan orang-orang yang ingin bekerja di luar negeri, pasca disahkannya UU No. 39 Tahun 2004 maka dibentuklah badan khusus untuk menangani TKI yakni BNP2TKI yang sebelumnya di bawah 
koordinasi Kementerian Tenaga Kerja dan Transmigrasi (Kemenakertrans)_.-Lebih lanjut, dalam perkembangan terakhir pemerintah telah memikirkan sinergi antara lembaga di dalam negeri dan luar negeri. Sehingga ada secercah harapan bagi TKI/PMI untuk mendapatkan perlindungan negara di negara penempatan melalui perwakilan Indonesia. Kolaborasi antara kebijakan di dalam negeri dan di luar negeri diharapkan dapat harmonis, sehingga kepentingan PMI/TKI yang juga merupakan warga negara Indonesia dapat terlindungi. Koordinasi yang lebih baik diharapkan dapat dilakukan pasca pemberlakuan UU No. 18 Tahun 2017 tentang Perlindungan Pekerja Migran Indonesia dengan adanya evaluasi atas UU terdahulu dan itikad politik pemerintah untuk hadir dalam sistem perlindungan menyeluruh bagi pekerja migran Indonesia di luar negeri.

\section{Pekerja Migran Indonesia dalam Masyarakat Ekonomi ASEAN}

\section{Agenda Ketenagakerjaan di ASEAN}

Agenda ketenagakerjaan di ASEAN merupakan salah satu bidang yang berkembang dengan cepat dan progresif untuk memberikan perlindungan terhadap pekerja migran di negara-negara anggota ASEAN. Salah satu hal yang dicapai oleh Komisi Pekerja Migran ASEAN (ASEAN Commission on Migrant Workers-ACMW) yakni pada tahun 2011 dengan dirumuskannya ASEAN Instrument on the Protection and Promotion of the Rights of Migrant Workers oleh ACMW Drafting Team (ACMW-DT) di Filipina, 12-13 September 2011. Sebagai tindak lanjut dari Declaration on the Protection and Promotion of the Rights of Migrant Workers, KTT ke-19 ASEAN menekankan komitmen untuk menyelesaikan penyusunan instrumen ASEAN tentang perlindungan dan pemajuan hak-hak pekerja migran. Dalam proses penyusunan instrumen tersebut, ACMW-DT telah setuju untuk melakukan tiga fase pembahasan, yaitu (1) fase documented, (2) fase undocumented, dan (3) legal approach. Capaian penting ini terlaksana saat Keketuaan Indonesia di ASEAN pada tahun 2011. (Kemlu, 2012:136)

Visi Masyarakat ASEAN Tahun 2020 yang disepakati pada KTT ASEAN di Bali tahun 2003 mengalami dinamika yang mendorong negara anggota ASEAN untuk memajukan visi tersebut menjadi tahun 2015 dan keputusan ini disepakati di Cebu, Filipina pada tahun 2007. Kemudian disusunlah peta jalan menuju masyarakat ASEAN yang terdiri dari pilar: ASEAN Political and Security Community (APSC), ASEAN Economic Community (AEC) dan ASEAN Socio-Cultural Community (ASSC). Peta jalan tersebut ditetapkan di Cha-am, Thailand pada tahun 2009.

Peta jalan tersebut salah satunya berisi cetak biru Masyarakat Ekonomi ASEAN (MEA) Tahun 2015 yang menekankan pada karakteristik kunci berikut: (a) pasar tunggal dan basis produksi, (b) kawasan ekonomi berdayasaing tinggi, (c) kawasan dengan pembangunan ekonomi yang setara, dan (d) kawasan yang sepenuhnya terintegrasi dengan ekonomi global. Arus bebas tenaga kerja terampil ASEAN (free flow of skilled labour) merupakan poin kelima dari karakteristik pasar tunggal dan basis produksi. Walaupun bagian ini tidak secara spesifik menyebutkan bidang yang mendapatkan keistimewaan untuk melakukan perpindahan secara bebas antar-negara, namun dalam cetak biru ini disebutkan bahwa penguatan melalui riset kapabilitas dari setiap negara anggota ASEAN untuk mempromosikan kemampuan tenaga kerja, penempatan tenaga kerja, dan pengembangan pasar tenaga kerja berbasis 
jaringan informasi diantara negara anggota ASEAN merupakan salah satu bagian penting dalam kesekapakatan MEA 2015. (ASEAN:2011, 29-30)

Berdasarkan cetak biru ini, jadwal strategi untuk MEA 2015 khususnya arus bebas tenaga kerja terampil ASEAN di bagi ke dalam dua aksi prioritas yakni tahun 2008-2009 dan 2014-2015. Fase yang seharusnya sudah dilalui oleh negara anggota ASEAN dalam fase 2008-2009 dengan dua poin aksi, yakni: (1) menyelesaikan Mutual Recognition Aggrements (MRAs) untuk bidang jasa profesional utama, termasuk sektor jasa investasi tahun 2008, dan (2) mengembangkan kompetensi inti (mengacu kepada kemampuan dan kualifikasi) untuk pekerjaan yang membutuhkan keterampilan terhadap prioritas sektor jasa tahun 2009 . Sedangkan fase 2014-2015 dengan poin aksi untuk mengembangkan kompetensi inti (mengacu ke kemampuan dan kualifikasi) untuk pekerjaan yang membutuhkan keterampilan terhadap seluruh sektor jasa tahun 2015. (ASEAN, 2011:54)

Penanganan pekerja migran di ASEAN ternyata tidak hanya menjadi ranah MEA, tetapi juga masuk dalam pembahasan Dewan Masyarakat Sosial Budaya ASEAN (MSBA) yang mengesahkan ASEAN Consensus on the Protection and Promotion of the Rights of Migrant Workers pada 13 September 2017 di Tagaytay City, Filipina. Konsensus ini disahkan oleh Menteri yang tergabung dalam MSBA sebagaimana dikutip dari situs web ASEAN sebagai sebuah terobosan "Culture of Prevention" di kawasan yang dikoordinasikan lintas sektor untuk mengatasi akar permasalahan dari berbagai permasalahan sosial seperti kekerasan ekstrim.

Selain itu, beberapa kajian mengenai tenaga kerja di negara anggota ASEAN dan kaitannya dengan masyarakat ASEAN pernah dipublikasikan oleh Nguyen Huy Hoàng (2013), Aniceto C. Orbeta, Jr (2013) dan Natenapha Wailerdsak (2013) dan Achmad Zulfikar (2015). Hoang dalam publikasinya menyatakan bahwa masyarakat ekonomi ASEAN merupakan peluang bagi negara anggota CLMV (Kamboja, Laos, Myanmar dan Viet Nam) dengan meningkatkan kualitas tenaga kerja agar dapat berintegrasi dalam pasar tenaga kerja ASEAN. Selanjutnya, Orbeta Jr. dalam publikasinya menyatakan bahwa pergerakan pekerja tidak terampil dan semi terampil seyogyanya dapat diakomodasi dalam masyarakat ekonomi ASEAN agar penerapannya dapat lebih baik dengan didasarkan pada realita bahwa sektor agrikultur, manufaktur dan jasa didominasi oleh pekerja tidak terampil dan semi terampil yang mendominasi migrasi kerja di ASEAN.

Kemudian, Wailerdsak menyatakan bahwa masyarakat ekonomi ASEAN menjadi salah satu motivasi bagi pemerintah Thailand untuk meningkatkan investasi di luar negeri, khususnya negara-negara ASEAN dalam rangka meningkatkan daya kompetisi dan menyelesaikan permasalahan kekurangan tenaga kerja. Sedangkan, Zulfikar menyatakan bahwa pemetaan posisi pekerja migran Indonesia menuju masyarakat Ekonomi ASEAN 2015 masih mengkhawatirkan. Profesi yang ditekuni oleh tenaga kerja Indonesia (TKI) yang bekerja di luar negeri hampir didominasi sektor informal yakni bekerja sebagai Penata Laksana Rumah Tangga (PLRT). Apabila dikaitkan dengan MEA 2015, maka profesi ini tidak menjanjikan untuk mendongkrak daya tawar pekerja Indonesia dalam MEA 2015. Hal ini sekaligus menunjukkan ironi bahwa bangsa Indonesia belum mampu memenuhi kebutuhan pasar tenaga kerja terampil di ASEAN.

Penjelasan di atas telah menggambarkan perjalanan ASEAN sebagai organisasi regional di bidang ketenagakerjaan. Sejak 2011, ASEAN telah menginisiasi pertemuan di 
Filipina terkait perlindungan dan pemajuan hak-hak pekerja migran. Agenda ini telah diadopsi juga ke dalam cetak biru Masyarakat Ekonomi ASEAN. Jika kita berbicara mengenai landasan kebijakan di kawasan, maka berbagai pertemuan yang diinisiasi di tingkat ASEAN dan dimasukkannya poin pekerja terampil dalam cetak biru MEA menunjukkan bahwa ASEAN memiliki komitmen untuk membuka akses pasar tenaga kerja di antara negara anggotanya. Hasil kajian dari peneliti Viet Nam, Filipina, Thailand dan Indonesia menunjukkan bahwa setiap negara memiliki tantangannya dalam merespon MEA. Hal ini disebabkan perbedaan kebijakan yang diberlakukan di masing-masing negara yang cenderung menjadi dinding pemisah bukan menjadi jembatan penyambung. Sehingga respon negara anggota ASEAN terhadap pekerja migran masih berbeda-beda satu sama lain.

\section{Respon Pemerintah Indonesia terhadap Mutual Recognitions Agreements (MRAs)}

Pemerintah Indonesia sebagaimana dikutip dari website Kementerian Ketenagakerjaan (Kemenaker) memberikan perhatian khusus terhadap 8 profesi yang menjadi prioritas karena Mutual Recognition Aggreements (MRA)-nya telah ditandatangai oleh negara anggota ASEAN. Delapan profesi prioritas yakni akuntansi, teknik, survei, arsitektur, keperawatan, kesehatan, perawatan gigi dan pariwisata. Sebagai tindaklanjut kesepakatan MRA ini, pemerintah pun terus berupaya untuk memperkuat kerjasama antara negara anggota ASEAN dalam menetapkan dan memperluas kerjasama implementasi MRA melalui peningkatan produktivitas dan kompetensi Sumber Daya Manusia (SDM) dengan membangun pusat pelatihan kejuruan. Selain itu, disiapkan juga pelatihan dasar untuk kompetensi dan sistem sertifikasi, akselerasi standar kompetensi nasional, serta menerapkan Kerangka Kualifikasi Nasional Indonesia (KKNI) dan memperkuat sistem kerjasama dengan lembaga yang terkait. (Kemenaker:2014)

Menteri Ketenagakerjaan, Hanif Dhakiri mengatakan sejumlah negara di kawasan ASEAN telah memiliki kerangka untuk mempromosikan pergerakan bebas tenaga kerja terampil. Tetapi, terdapat pula sebagian negara lain belum memiliki kerangka tersebut meliputi kualifikasi nasional penuh sekaligus penerapan sertifikasi tenaga kerja. Pelaksanaan MEA diakui Menaker dapat menimbulkan dampak negatif terhadap dunia ketenagakerjaan di Indonesia jika tenaga kerja kita tidak menyiapkan kompetensinya dengan baik. "Oleh karena itu kompetensi harus kita percepat, sertifikasinya juga. MEA masih 15 bulan lagi (diterapkan), kita akan gunakan waktu yang tersisa untuk melakukan percepatan-percepatan itu. (Kemenaker, 2014)

Dibukanya delapan profesi tersebut tentunya menjadi pekerjaan rumah pemerintah untuk menjadikan para pelakunya menjadi berdayasaing dengan negara anggota ASEAN lainnya sesuai dengan kompetensi yang diharapkan dari profesi tersebut. Dari delapan profesi yang telah disepakati, hanya sektor jasa pariwisata yang dianggap paling siap untuk menghadapi MEA 2015. Hal ini berbeda dibandingkan tenaga kerja jasa dari sektor lainnya.

Ketua Komite Tetap Sistem Sertifikasi Kompetensi SDM, Sumarna Abdurahman dikutip dari Tempo mengemukakan bahwa saat ini tenaga kerja sektor pariwisata sudah mempunyai Standar Kompetensi Kerja Nasional Indonesia (SKKNI), lembaga pendidikan, dan latihan serta Lembaga Sertifikasi Profesi. "Sektor pariwista tak masalah jika sudah menandatangani mutual recognition agreement (MRA), ungkapnya. (Tempo, 2014) Walaupun demikian dikutip dari Suara Pembaruan, Sumarna tetap mengkhawatirkan sektor 
pariwisata ini akan disesaki oleh tenaga kerja asal Thailand. "Mereka sudah belajar bahasa indonesia sekarang, jangan heran kalau pemandu di Bali nanti dari Thailand", tegasnya.

Sumarna juga mengatakan bahwa perawat dan dokter asal Filipina yang juga telah mempelajari bahasa Indonesia akan menjadi alternatif untuk mengisi kekurangan di Indonesia. "BPJS jadi peluang bagi mereka. Kekurangan perawat dan dokter di Puskesmas di pelosok Indonesia pun bisa dimasuki mereka, bahkan jika belum ada Puskesmasnya pun mungkin mereka akan berinvestasi," ujarnya. (Suara Pembaruan, 2014)Sedangkan sektor konstruksi yang diharapkan dapat menjadi peluang Indonesia akhirnya menjadi salah satu lapangan kerja yang akan diperebutkan dengan Malaysia. Banyak diantara kontraktor Malaysia telah memegang sertifikat kompetensi. Lain halnya dengan kontraktor Indonesia yang belum memegang sertifikat kompetensi sehingga belum dihargai sebagai tenaga kerja formal. (Suara Pembaruan, 2014)

Penjelasan dari pemerintah seperti yang telah dipaparkan di atas tentunya memberikan angin segar bagi pekerja migran Indonesia dikarenakan masih diberikan pembatasan akses dalam pasar tenaga kerja ASEAN. Dikarenakan baru delapan profesi prioritas yang disepakati oleh negara anggota ASEAN untuk diintegrasikan antara lain: akuntansi, teknik, survei, arsitektur, keperawatan, kesehatan, perawatan gigi dan pariwisata. Walaupun demikian, Indonesia patut untuk berbenah diri dalam mempersiapkan pekerja migrannya untuk bersaing dengan pekerja migran dari negara anggota ASEAN lainnya. Di samping itu, kemungkinan ditambahkannya profesi yang dibuka seiring kesepakatan MRAs membuat Indonesia harus bergegas agar tidak ketinggalan.

\section{Pekerja Migran Indonesia dalam Konstelasi Pasar Tenaga Kerja di Era MEA}

\section{Regionalisme}

Di dalam studi Hubungan Internasional, Regionalisme memiliki irisan studi yang sangat erat dengan studi kawasan (area studies). Bahkan dalam aplikasi analisis, istilah region (kawasan) dengan regionalisme seringkali tumpang tindih. Oleh karena itu, definisi tentang regionalisme akan banyak mengambil dari definisi-definisi yang berkembang dalam studi kawasan. Menurut Mansbaach dalam Nuraeini S dkk. (2010:1), region atau kawasan adalah "pengelompokan regional diidentifikasi dari basis kedekatan geografis, budaya, perdagangan dan saling ketergantungan ekonomi yang saling menguntungkan, komunikasi serta keikutsertaan dalam organisasi internasional". Lebih lanjut, Coulumbis dan Wolfe dalam Nuraeini S dkk. (2010:1-2) menyatakan ada empat kriteria untuk menunjuk sebuah kawasan yang ditentukan oleh tujuan analisis, salah satu yang terkait dengan ASEAN yakni kriteria geografis yakni mengelompokkan negara berdasarkan lokasinya dalam benua, subbenua, kepulauan dan lain sebagainya seperti: Eropa dan Asia, termasuk Asia Tenggara.

Teori konvergensi (convergence theory) dikemukakan oleh Hurrel yang merupakan salah satu dari tiga cara bagaimana faktor-faktor domestik terkait dengan regionalisme kontemporer, selain regionalisme dan state coherence dan tipe rezim dan demokratisasi. Teori ini memahami dinamika kerjasama regional dan integrasi ekonomi dalam kerangka bertemunya atau bersatunya berbagai pilihan kebijakan domestik dari negara-negara. Menurut Hurrel dalam Nuraeini S dkk. (2010:62-63) teori konvergensi memang terlihat sangat menekankan pada permasalahan ekonomi dan kebijakan perekonomian suatu negara, 
namun kita dapat menggunakan teori ini pada tataran permasalahan yang lebih umum dalam regionalisme kontemporer.

Masyarakat ekonomi ASEAN bersama dua pilar lainnya merupakan kebijakan yang telah disepakati 10 negara anggota ASEAN. Kebijakan yang menjadi fokus dalam kajian ini yakni bidang ketenagakerjaan. Negara-negara anggota ASEAN menyadari bahwa potensi penyerapan tenaga kerja di antara negara-negara anggota ASEAN sangat tinggi. Utamanya, Indonesia sebagai anggota dengan luas wilayah terbesar diantara negara anggota ASEAN yang lain. Dalam konteks ketenagakerjaan, negara anggota ASEAN dapat dibagi ke dalam dua pihak yakni negara pengirim (sending countries) dan negara penerima (receiving countries). Indonesia, Filipina, Kamboja, Laos, Myanmar dan Viet Nam merupakan negara pengirim, sedangkan Malaysia, Singapura, Brunei Darussalam dan Thailand merupakan negara penerima. Tetapi hal yang mempertemukan kepentingan negara-negara ini yakni mereka dapat memasuki pasar tenaga kerja satu sama lain sebagai satu kawasan. Kerangka kebijakan ini akan digunakan untuk menjelaskan bagaimana nasib pekerja migran Indonesia dalam konstelasi pasar tenaga kerja di era masyarakat ekonomi ASEAN.

\section{Model Analisis SWOT}

Analisis SWOT adalah instrumen yang digunakan untuk melakukan analisis strategis. Menurut Robert Simbolon (1999), analisis SWOT merupakan suatu alat yang efektif dalam membantu menstrukturkan masalah, terutama dengan melakukan analisis atas lingkungan strategis, yang lazim disebut sebagai lingkungan internal dan lingkungan eksternal. Dalam lingkungan internal dan eksternal ini pada dasarnya terdapat empat unsur yang selalu dimiliki dan dihadapi, yaitu secara internal memiliki sejumlah kekuatan-kekuatan (Strengths) dan kelemahan-kelemahan (Weaknesses), dan secara eksternal akan berhadapan dengan berbagai peluang-peluang (Oppotunities) dan ancaman-ancaman (Threats).

Gambar1. Ilustrasi Analisis SWOT

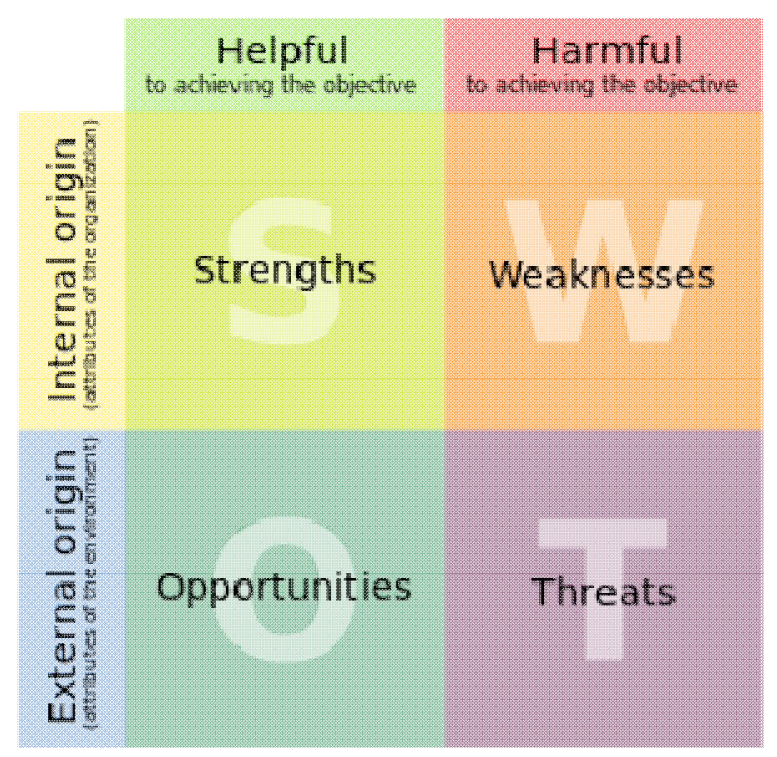

Kegiatan yang paling penting dalam proses analisis SWOT adalah memahami seluruh informasi dalam suatu kasus, menganalisis situasi untuk mengetahui isu apa yang sedang 
terjadi dan memutuskan tindakan apa yang harus segera dilakukan utuk memecahkan masalah (Rangkuti, 2001:14). SWOT merupakan singkatan dari strengths (kekuatankekuatan), weaknesses (kelemahan-kelemahan), opportunities (peluang-peluang) dan threats (ancaman-ancaman). Pengertian-pengertian kekuatan, kelemahan, peluang dan ancaman dalam analsis SWOT adalah sebagai berikut :

1. Kekuatan (strengths) adalah sumber daya, keterampilan atau keunggulan lain relatif terhadap pesaing;

2. Kelemahan (weaknesses) adalah keterbatasan/kekurangan dalam sumber daya alam, keterampilan dan kemampuan yang secara serius menghalangi kinerja;

3. Peluang (opportunities) adalah situasi/kecenderungan utama yang menguntungkan;

4. Ancaman (threats) adalah situasi/kecenderungan utama yang tidak menguntungkan. (Amin W.T, 1994: 74-75)

Analisis ini didasarkan pada logika yang dapat memaksimalkan kekuatan dan peluang, namun secara bersamaan dapat meminimalkan kelemahan dan ancaman. Proses pengambilan keputusan harus menganalisis faktor-faktor strategis dalam kondisi saat itu. Hal tersebut disebut dengan analisis situasi, model yang paling popular disebut analisis SWOT. Petunjuk umum yang sering diberikan untuk perumusan adalah: (1) memanfaatkan kesempatan dan kekuatan (O dan $\mathrm{S})$. Analisis ini diharapkan membuahkan rencana jangka panjang; atau (2) mengatasi atau mengurangi ancaman dan kelemahan ( $\mathrm{T}$ dan $\mathrm{W}$ ). Analisa ini lebih condong menghasilkan rencana jangka pendek, yaitu rencana perbaikan (short-term improvement plan).

Tahap awal proses penetapan strategi adalah menaksir kekuatan, kelemahan, kesempatan, dan ancaman yang dimiliki organisasi. Analisa SWOT memungkinkan organisasi memformulasikan dan mengimplementasikan strategi utama sebagai tahap lanjut pelaksanaan dan tujuan organiasasi, dalam analisa SWOT informasi dikumpulkan dan dianalisa. Hasil analisa dapat menyebabkan dilakukan perubahan pada misi, tujuan, kebijaksanaan, atau strategi yang sedang berjalan.

Dalam penyusunan suatu rencana yang baik, perlu diketahui daya dan dana yang dimiliki pada saat akan memulai usaha, mengetahui segala unsur kekuatan yang dimiliki, maupun segala kelemahan yang ada. Data yang terkumpul mengenai faktor-faktor internal tersebut merupakan potensi di dalam melaksanakan usaha yang direncanakan. Di lain pihak perlu diperhatikan faktor-faktor eksternal yang akan dihadapi yaitu peluang-peluang atau kesempatan yang ada atau yang diperhatikan akan timbul dan ancaman atau hambatan yang diperkirakan akan muncul dan mempengaruhi usaha yang dilakaukan.

Selanjutnya analisis SWOT ini digunakan untuk memetakan posisi pekerja migran Indonesia dalam konstelasi pasar tenaga kerja di era MEA serta mengukur kekuatan, kelemahan, peluang dan ancaman dalam era masyarakat ekonomi ASEAN. Berdasarkan kerangka teoretik, maka pada bagian ini akan dipetakan posisi pekerja (migran) Indonesia terhadap pekerja di ASEAN dengan menggunakan model analisis SWOT. Selengkapnya sebagai berikut. 
Tabel 3. Analisis SWOT Tenaga Kerja Indonesia dan ASEAN

\begin{tabular}{|c|c|c|}
\hline \multirow[b]{2}{*}{ TK Indonesia } & SW & OT \\
\hline & $\begin{array}{l}\text { Strength } \\
\text { - Jumlah angkatan kerja yang besar. } \\
\text { - TKI telah tersebar di } 9 \text { negara } \\
\text { ASEAN lainnya. } \\
\text { Weakness } \\
\text { - TKI masih berketerampilan rendah } \\
\text { (unskilled labor) } \\
\text { - Data TKI pemerintah belum } \\
\text { akuntabel. }\end{array}$ & $\begin{array}{l}\text { Opportunity } \\
\text { - Pasar kerja ASEAN sangat } \\
\text { menjanjikan. } \\
\text { - Peluang kerja di sektor formal } \\
\text { terbuka luas. } \\
\text { Threat } \\
\text { - TKI tidak berdokumen dan ilegal. } \\
\text { - Penyiksaan TKI dan gejolak } \\
\text { sosial. }\end{array}$ \\
\hline \multirow[b]{2}{*}{ TK ASEAN } & SW & OT \\
\hline & $\begin{array}{l}\text { Strength } \\
\text { - } 8 \text { profesi tenaga kerja terampil } \\
\text { disepakati (skilled labor) boleh } \\
\text { bergerak bebas di ASEAN. } \\
\text { - Filipina dan Indonesia merupakan } \\
\text { pengirim tenaga kerja terbesar di } \\
\text { Asia. } \\
\text { Weakness } \\
\text { - Tidak semua negara memiliki } \\
\text { skilled labor yang dipersyaratkan. } \\
\text { - Standar perlakuan dan pengupahan } \\
\text { pekerja di masing-masing negara } \\
\text { ASEAN masih timpang. }\end{array}$ & $\begin{array}{l}\text { Opportunity } \\
\text { - Populasi di ASEAN } \pm 600 \text { juta } \\
\text { jiwa. } \\
\text { - Indonesia menjadi pasar kerja } \\
\text { terbesar diantara negara ASEAN } \\
\text { dengan populasi } \pm 250 \text { juta jiwa. } \\
\text { Threat } \\
\text { - Penyelundupan manusia berkedok } \\
\text { penyaluran tenaga kerja. } \\
\text { - Konflik yang masih terjadi di } \\
\text { beberapa negara anggota ASEAN } \\
\text { yang mempengaruhi stabilitas } \\
\text { ekonomi dan penyerapan tenaga } \\
\text { kerja. }\end{array}$ \\
\hline
\end{tabular}

Dalam analisis SWOT yang telah dipaparkan di atas maka terlihat hubungan atau interaksi antar unsur-unsur internal, yaitu kekuatan dan kelemahan terhadap unsur-unsur eksternal yaitu peluang dan ancaman. Interaksi yang terjadi antara unsur internal dan eksternal ini dapat disusun menjadi strategi berikut:

1. Strategi kekuatan-kesempatan ( $\mathrm{S}$ dan $\mathrm{O}$ atau maxi-maxi). Strategi yang dihasilkan pada kombinasi ini adalah memanfaatkan kekuatan atas peluang yang telah diidentifikasi;

2. Strategi kelemahan-kesempatan (W dan $\mathrm{O}$ atau mini-maxi). Kesempatan yang dapat diidentifikasi tidak mungkin dimanfaatkan karena kelemahan yang dimiliki;

3. Strategi kekuatan-ancaman ( $\mathrm{S}$ atau $\mathrm{T}$ atau maxi-mini). Dalam analisa ancaman ditemukan kebutuhan untuk mengatasinya. Strategi ini mencoba mencari kekuatan yang dimiliki yang dapat mengurangi atau menangkal ancaman; dan

4. Strategi kelemahan-ancaman (W dan $\mathrm{T}$ atau mini-mini). Dalam situasi menghadapi ancaman dan sekaligus kelemahan intern, strategi yang umumnya dilakukan adalah "keluar" dari situasi yang terjepit tersebut. 
Berdasarkan strategi di atas, maka dapat dirumuskan strategi yang tepat dan dapat diterapkan bagi tenaga kerja Indonesia (TKI) dan tenaga kerja ASEAN.

\section{Strategi Tenaga Kerja Indonesia}

1. Strategi SO. Jumlah angkatan kerja yang besar merupakan kekuatan bagi Indonesia untuk dikelola secara sungguh-sungguh sehingga dapat mengoptimalkan peluang pasar kerja ASEAN di sektor formal yang menjanjikan. Maka pekerjaan rumah bagi pemerintah Indonesia yakni membuka balai latihan kerja untuk melatih tenaga kerja sektor formal Indonesia untuk ditempatkan di 9 negara ASEAN lainnya. Di samping pemerintah juga harus memperhatikan pekerjanya yang telah bekerja di negara anggota ASEAN lainnya.

2. Strategi WO. Pekerja Indonesia memiliki kelemahan di sisi keterampilan. Saat ini masih banyak TKI yang bekerja di sektor informal. Sedangkan di sisi pemerintah, data TKI yang belum akuntabel masih menjadi hambatan untuk mencari solusi dalam rangka membangun jaringan dengan TKI yang telah bekerja di kawasan ASEAN. Apabila hal ini dibiarkan maka pasar kerja ASEAN yang menjanjikan dan peluang kerja sektor formal yang terbuka justru akan tertutup bagi pekerja Indonesia.

3. Strategi ST. TKI yang tidak berdokumen dan ilegal serta gejolak masyarakat atas penyiksaan yang dilakukan terhadap TKI di negara penempatan merupakan ancaman bagi TKI. Oleh karena itu, pemerintah harus lebih aktif untuk memfasilitasi TKI yang telah tersebar di 9 negara ASEAN lainnya untuk membangun komunikasi yang baik agar ancaman yang dapat terjadi sewaktu-waktu dapat diantisipasi.

4. Strategi WT. Kelemahan dan ancaman TKI menitikberatkan pada optimalisasi peran pemerintah. Rendahnya keterampilan TKI, dan data TKI yang belum akuntabel berkaitan dengan tingginya jumlah TKI yang tidak berdokumen dan ilegal di negara penempatan yang berakibat hilangnya hak-hak yang harusnya diterima oleh TKI. Oleh karena itu dalam menjalankan strategi WT, maka pemerintah dalam hal ini Badan Nasional Penempatan dan Perlindungan TKI (BNP2TKI), Kementerian Ketenagakerjaan dan Kementerian Luar Negeri harus bersinergi untuk meningkatkan kapasitas TKI agar terampil, dan juga merapikan data TKI di negara tujuan maupun yang akan berangkat agar data yang dipegang oleh pemerintah dapat dipertanggungjawabkan.

\section{Strategi Tenaga Kerja ASEAN}

1. Strategi SO. Tenaga kerja terampil (skilled labor) yang dimiliki oleh negara anggota ASEAN dengan 8 profesi sesuai kriteria berdasarkan MRAs yakni: akuntansi, teknik, survei, arsitektur, keperawatan, kesehatan, perawatan gigi dan pariwisata akan bebas bergerak di antara \pm 600 juta jiwa populasi di ASEAN. Sedangkan, Filipina dan Indonesia merupakan negara pengirim tenaga kerja terbesar di Asia seharusnya mampu memanfaatkan peluang tersebut. Di sisi lain, Indonesia juga berperan sebagai negara penerima dengan populasi yang mencapai \pm 250 juta jiwa.

2. Strategi WO. Walaupun peluang kerja di negara anggota ASEAN yang terbuka luas, namun tidak semua negara memiliki tenaga kerja terampil yang dipersyaratkan dan juga standar perlakuan dan pengupahan yang berbeda di masing-masing negara ASEAN. Sehingga arus tenaga kerja di ASEAN tidak berimbang dan justru hanya terpusat pada 
beberapa negara saja. Seperti, TKI yang bekerja di Malaysia sebagai tenaga kerja tidak terampil sangat besar, sedangkan TK Malaysia sangat sedikit yang bekerja di Indonesia dan justru mereka mencari pasar kerja di luar kawasan ASEAN.

3. Strategi ST. Ancaman bagi TK ASEAN adalah penyelundupan manusia (people's smuggling) yang berkedok penyaluran tenaga kerja yang saat ini termasuk trans-national crime. Ditambah lagi dengan konflik yang masih terjadi di beberapa negara anggota ASEAN yang berimbas pada stabilitas ekonomi negara tersebut. Maka, ASEAN dengan mekanisme penyaluran tenaga terampil dapat meminimalisir ancaman dengan menunjuk otoritas Ketenagakerjaan masing-masing negara untuk memfasilitasi serta mengawasi penyaluran tenaga kerja, utamanya pada negara-negara pengirim tenaga kerja seperti Indonesia dan Filipina.

4. Strategi WT. Kelemahan dan ancaman TK ASEAN terletak pada kapasitas negara dalam menghasilkan tenaga kerja terampil dan melakukan standarisasi perlakuan dan pengupahan. Hal ini dimanfaatkan oleh oknum penyelundup manusia yang berkedok sebagai penyalur tenaga kerja untuk memanfaatkan tenaga kerja tidak terampil untuk dijanjikan bekerja di luar negeri dengan gaji tinggi, padahal mereka disalurkan secara ilegal yang justru membahayakan diri mereka sendiri. Oleh karena itu diperlukan kerjasama yang kuat antar penegak hukum di ASEAN untuk menindak pelaku penyelundupan manusia sebagai bagian dari upaya perlindungan pekerja migran di kawasan Asia Tenggara.

\section{Catatan Penutup}

Menyikapi penanganan pekerja migran tentu patut mempertimbangkan berbagai aspek salah satu yang utama adalah insting nomaden yang dimiliki oleh manusia. Mukidi dan Rahing pada pengantar bagian ini merepresentasikan potret masyarakat yang memiliki kesadaran yang rendah terhadap aturan yang dibuat oleh pemerintah. Namun demikian, masyarakat yang memiliki kesadaran yang rendah tersebut tidak dapat disalahkan sepenuhnya, diperlukan peran pemerintah untuk meningkatkan kesadaran masyarakat agar regulasi dapat ditaati dan disosialisasikan secara menyeluruh. Oleh karena itu, insting nomaden ini patut menjadi pijakan berpikir oleh para pengambil kebijakan di Indonesia dan ASEAN untuk mengambil kebijakan strategis dan berdampak bagi para pelintas batas, utamanya pekerja migran di ASEAN.

Posisi Indonesia dalam masyarakat ekonomi ASEAN berdasarkan kajian penulis justru menjadi 'mangsa' empuk di kawasan dengan sumber daya alam dan pertumbuhan ekonomi yang terus berkembang. Pekerja migran Indonesia yang masih didominasi tenaga kerja tidak terampil dan semi terampil sudah harus dibenahi dengan serangkaian kebijakan pemerintah untuk meningkatkan kapasitas dan juga daya saing mereka. Pemerintah dan pemangku kepentingan terkait juga tidak boleh menutup mata bahwa masih banyak pekerja migran Indonesia yang memiliki tingkat pendidikan yang tidak memadai, sehingga mereka mudah diperdaya. Oleh karena itu perlu dilakukan pengkajian mendalam untuk model perlindungan pekerja migran Indonesia yang lebih baik.

Indonesia juga harus membuka diri bagi perbaikan sistem penempatan dan perlindungan TKI. Indonesia bisa belajar dari Filipina yang mampu mengelola pekerja migrannya dengan cukup baik. Selain itu, kerjasama bilateral dan diplomasi ketenagakerjaan 
dengan negara tujuan kerja harus diintensifkan oleh Indonesia seperti Malaysia, Singapura, Brunei Darussalam dan Thailand. Indonesia bersama Filipina harus menjadi pemimpin di kawasan dalam pemajuan hak-hak pekerja migran bagi negara anggota ASEAN yang lain. Perlu diingat bahwa 193 negara anggota Perserikatan Bangsa-Bangsa (PBB) pada 19 September 2016 telah mengadakan pertemuan tingkat tinggi dan telah menghasilkan deklarasi politik berbentuk New York Declaration for Refugees and Migrants yang salahs atu rekomendasinya mendorong negara-negara anggota yang menandatangani Deklarasi ini untuk menghormati hak-hak pekerja migran.

Ditambah lagi dengan konsensus pekerja migran ASEAN yang disahkan oleh Dewan Masyarakat Sosial Budaya ASEAN (MSBA) yakni ASEAN Consensus on the Protection and Promotion of the Rights of Migrant Workers pada 13 September 2017 di Tagaytay City, Filipina. Serta bagi Indonesia, pengesahan UU No. 18 Tahun 2017 tentang Perlindungan Pekerja Migran Indonesia yang mulai berlaku sejak diundangkan pada 22 November 2017 patut menjadi momentum pembenahan perlindungan pekerja migran Indonesia secara menyeluruh. Berbicara mengenai tenaga kerja terampil, beberapa negara anggota ASEAN sudah siap melakukan ekspansi pasar. Hal ini patut didukung kesiapan sumber daya manusia dan sarana prasarana pendukung yang telah terintegrasi Mutual Recognition Agreements (MRAs). Hal yang patut diperhatikan oleh Indonesia berdasarkan analisis SWOT yang telah dilakukan yakni Indonesia memiliki penduduk yang besar dan juga jumlah angkatan kerja yang besar. Demikian juga dengan persebaran tenaga kerjanya di kawasan Asia Tenggara. Sedangkan kelemahan yang harus diantisipasi yakni masih rendahnya kualitas tenaga kerja Indonesia (unskilled labor) dan data pemerintah yang belum akuntabel. Adapun peluang Indonesia yakni pasar kerja ASEAN yang menjanjikan dengan peluang kerja di sektor formal yang terbuka luas. Sedangkan ancamannya yakni TKI yang tidak berdokumen dan ilegal serta penyiksaan TKI dan instabilitas kawasan.

Mengantisipasi ancaman yang muncul dari analisis SWOT kajian ini, maka diperlukan kajian lebih lanjut mengenai kaitan antara keamanan non-tradisional dengan semakin berkembangnya pasar tenaga kerja di kawasan Asia Tenggara. Sebagai gambaran awal bahwa permasalahan yang telah teridentifikasi yakni TKI yang tidak berdokumen dan ilegal serta penyiksaan TKI. Sedangkan kajian yang pernah penulis lakukan tentang Efektivitas Peran ASEAN dalam Mengatasi Masalah Human Security di Kawasan Asia Tenggara memetakan bahwa permasalahan buruh (pekerja) migran seringkali menjadi pemicu eskalasi konflik bilateral antar-negara anggota ASEAN. Beberapa kasus yang pernah terjadi antara Indonesia-Malaysia maupun Indonesia-Singapura. Hingga potensi terjadinya kejahatan transnasional yang diakibatkan penempatan pekerja migran yang tidak sesuai prosedur yang merupakan modus perdagangan manusia. Penjelasan ini menunjukkan hubungan jelas antara permasalahan pekerja migran dengan ancaman keamanan nontradisional yang dapat dialami oleh pekerja migran Indonesia di negara anggota ASEAN lainnya dan tentu patut diantisipasi sebagai wujud perlindungan terhadap hak-hak pekerja migran yang juga sebagai bagian dari hak asasi (manusia) untuk mendapatkan pekerjaan yang layak. 


\section{REFERENCES}

\section{Buku}

Afriana, Linda dan Rishang Haryo Tutuko. (2015). Mapping and Role of Indonesian Skilled Workers and ASEAN Services Liberalization for Creating Strategic Value Different Sectors in the Mutual Recognition Agreement (MRA) Framework. Prosiding. International Conference on ASEAN Studies. Yogyakarta: ASEAN Studies Center Universitas Gadjah Mada.

Association of Southeast Asian Nations. (2011). Roadmap for an ASEAN Community 20092015. Jakarta: Sekretariat ASEAN.

Caporaso, James A. dan David P. Levine. (2008). Teori-Teori Ekonomi Politik. Yogyakarta: Pustaka Pelajar.

Cipto, Bambang. (2007). Hubungan Internasional di Asia Tenggara: Teropong terhadap Dinamika, Realitas dan Masa Depan. Yogyakarta: Pustaka Pelajar.

Deliarnov. (2006). Ekonomi Politik. Jakarta: Penerbit Erlangga.

Dwi Yuwono, Ismantoro. (2011). Hak dan Kewajiban Hukum Tenaga Kerja Indonesia di Luar Negeri. Yogyakarta: Pustaka Yustisia.

Hoàng, Nguyen Huy. (2013). Toward an Integrated ASEAN Labor Market Prospects and Challenges for CLMV Countries. VNU Journal of Economics and Business Vol. 29, No. 5E (2013) 34-42.

Kementerian Luar Negeri. (2012). ASEAN Selayang Pandang. Jakarta: Direktorat Jenderal Kerjasama ASEAN Kementerian Luar Negeri.

Kementerian Tenaga Kerja dan Transmigrasi. (2011). Perkembangan Ketenagakerjaan di Indonesia. Jakarta: Kemenakertrans.

Luhulima, CPF., dkk. (2008). Masyarakat Asia Tenggara Menuju Komunitas ASEAN 2015. Yogyakarta: Pustaka Pelajar.

Mas'oed Mochtar. (2003). Ekonomi-Politik Internasional dan Pembangunan. Yogyakarta: Pustaka Pelajar.

Nugroho, Riant. (2014). Kebijakan Publik di Negara-negara Berkembang. Yogyakarta: Pustaka Pelajar.

Orbeta Jr, Aniceto C. (2013). Enhancing Labor Mobility in ASEAN: Focus on Lower Skilled Workers. Discussion Paper Series. Filipina: Philippine Institute for Development Studies.

Suparman, Nuraeini, Deasy Silvya, dan Arfin Sudirman. (2010). Regionalisme dalam Studi Hubungan Internasional. Yogyakarta: Pustaka Pelajar.

Wailerdsak, Natenapha. (2013). Impacts of the ASEAN Economic Community on Labour Market and Human Resource Management in Thailand. South East Asia Journal of Contemporary Business, Economics and Law, Vol. 2, Issue 2 (June) 2013.

Zulfikar, Achmad, Suleman, dan Aan Febriadi. (2013). Penguatan Kapasitas Tenaga Kerja Internasional Indonesia dalam Aspek Etika dan Hukum di Kalangan Penyalur Jasa TKI di Yogyakarta. Program Kreativitas Mahasiswa-Penelitian Didanai DIKTI Tahun 2013, Universitas Muhammadiyah Yogyakarta.

Zulfikar, Achmad. (2013). Alasan Pemerintah Indonesia Meratifikasi Konvensi Internasional Perlindungan Hak Pekerja Migran Tahun 2012. Skripsi. Yogyakarta: Universitas Muhammadiyah Yogyakarta.

Zulfikar, Achmad. (2013). Efektivitas Peran ASEAN dalam Mengatasi Masalah Human Security di Kawasan Asia Tenggara dalam Prosiding "How ASEAN as an Institutional Platform Can Address the Security Problem in the Region?”. Bandung: Universitas Katolik Parahyangan. Retrieved from https://osf.io/preprints/inarxiv/8Q264/ 
Zulfikar, Achmad. (2015). Rasionalitas Ekonomi Politik dalam Ratifikasi Konvensi Internasional Perlindungan Hak Pekerja Migran Tahun 2012. Jurnal The Politics Vol. 1 No. 1 Januari 2015. Makassar: Magister Ilmu Politik Universitas Hasanuddin. hh. 3749. hh. 37-49. (http://journal.unhas.ac.id/index.php/politics/article/view/128)

Zulfikar, Achmad. (2015). Mapping the Position of Indonesian Migrant Workers towards ASEAN Economic Community 2015. Makalah. Disajikan pada $1^{\text {st }}$ International Conference of Journal Government and Politics di Universitas Muhammadiyah Yogyakarta, 14 Maret 2015.

Zulfikar, Achmad. (2016). Analisis Ekonomi Politik Pemenuhan Hak-Hak Pekerja Migran asal Sulawesi Selatan di Malaysia. Tesis. Makassar: Magister Ilmu Politik Universitas Hasanuddin.

\section{Internet}

Antara Jatim. (2012). Kapan Kekerasan TKI akan Berakhir? http://www.antarajatim.com/lihat/berita/87574/kapan-kekerasan-tki-akan-berakhir-, diakses 20 Desember 2016.

ASEAN. (2017). ASEAN Consensus on the Protection and Promotion of the Rights of Migrant Workers - http://asean.org/storage/2017/11/ASEAN-Consensus-on-theProtection-and-Promotion-of-the-Rights-of-Migrant-Workers1.pdf ， diakses 18 September 2017.

ASEAN. (2017). ASEAN to Protect and Promote Rights of Migrant Workers http://asean.org/asean-to-protect-and-promote-rights-of-migrant-workers/, diakses 19 September 2017.

Bisnis. (2017). Setelah terkatung 7 Tahun, UU Perlindungan Pekerja Migran Disahkan http://industri.bisnis.com/read/20171025/12/702946/setelah-terkatung-7-tahun-uuperlindungan-pekerja-migran-disahkan, diakses 25 Oktober 2017.

Kementerian Ketenagakerjaan. (2014). Hadapi MEA 2015 Pemerintah Fokus Siapkan 8 Profesi Prioritas. http://ppid.depnakertrans.go.id/hadapi-mea-2015-pemerintah-fokussiapkan-8-profesi-prioritas. Diakses 20 Desember 2016.

Suara Pembaruan. (2014). Indonesia Terancam Jadi Pasar Tenaga Kerja ASEAN. http://sp.beritasatu.com/home/indonesia-terancam-jadi-pasar-tenaga-kerja-asean/54233. Diakses 20 Desember 2016.

Pikiran Rakyat. (2016). Di Era MEA TKA Tak Bisa Dibendung. http://www.pikiranrakyat.com/ekonomi/2016/01/21/358010/di-era-mea-tka-tak-bisa-dibendung. Diakses 20 Desember 2016.

Tempo. (2014). Hanya Tenaga Kerja Ini yang Siap di Pasar Bebas?. http://www.tempo.co/read/news/2014/05/02/090574773/Hanya-Tenaga-Kerja-Ini-yangSiap-di-Pasar-Bebas. Diakses 20 Desember 2016.

United Nations. (2016). New York Declaration for Refugees and Migrants (A/RES/71/1) http://refugeesmigrants.un.org/resolutions-and-conventions. Diakses 20 Desember 2016. 